IZA DP No. 10332

How Does the Minimum Wage Affect Firm Investments in Fixed and Human Capital? Evidence from China

Tobias Haepp

Carl Lin

October 2016 


\title{
How Does the Minimum Wage Affect Firm Investments in Fixed and Human Capital? Evidence from China
}

\author{
Tobias Haepp \\ Peking University \\ Carl Lin \\ Bucknell University \\ and IZA
}

\author{
IZA \\ P.O. Box 7240 \\ 53072 Bonn \\ Germany \\ Phone: +49-228-3894-0 \\ Fax: +49-228-3894-180 \\ E-mail: iza@iza.org
}

Any opinions expressed here are those of the author(s) and not those of IZA. Research published in this series may include views on policy, but the institute itself takes no institutional policy positions. The IZA research network is committed to the IZA Guiding Principles of Research Integrity.

The Institute for the Study of Labor (IZA) in Bonn is a local and virtual international research center and a place of communication between science, politics and business. IZA is an independent nonprofit organization supported by Deutsche Post Foundation. The center is associated with the University of Bonn and offers a stimulating research environment through its international network, workshops and conferences, data service, project support, research visits and doctoral program. IZA engages in (i) original and internationally competitive research in all fields of labor economics, (ii) development of policy concepts, and (iii) dissemination of research results and concepts to the interested public.

IZA Discussion Papers often represent preliminary work and are circulated to encourage discussion. Citation of such a paper should account for its provisional character. A revised version may be available directly from the author. 


\section{ABSTRACT \\ How Does the Minimum Wage Affect Firm Investments in Fixed and Human Capital? Evidence from China*}

This paper empirically analyzes the impact of Chinese minimum wage regulations on the firm decision to invest in physical and human capital. We exploit the geographical and intertemporal variations of county-level minimum wages in a panel data set of all state-owned and all above-scale non-state-owned Chinese firms covering the introduction of the new Chinese minimum wage regulations in 2004. In our basic regressions including all Chinese firms, we find significant negative effects of the minimum wage on human capital investment rates and no overall effects on fixed capital investment rates. When grouping firms by their ownership structure, we find that these results hold for most firms. Foreign-owned firms are an exception to some extent, because the likelihood that they invest in human capital has not decreased in response to the policy.

JEL Classification: J31, J38

Keywords: minimum wage, firm investment, fixed capital, human capital

Corresponding author:

Tobias Haepp

National School of Development

Peking University

5 Yiheyuan Road

Haidian District, 100871 Beijing

China

E-mail: haepp@pku.edu.cn

\footnotetext{
* The authors thank Jarko Fidrmuc, Daniel S. Hamermesh, Li-Hsuan Huang, Hong Hwang, Sangheon Lee, David Neumark, Li Shi, Paul J.Wolfson, Linxiang Ye, Ruoh-Rong Yu and seminar participants at the "Fourth SOLE/EALE World Conference" of the Society of Labor Economists (SOLE) and the European Association of Labour Economists (EALE), the " 2 nd Henan Symposium on Development and Institutional Economics", the "4th Regulating for Decent Work Conference" organized by the International Labour Organization (ILO), the workshop "The German Minimum Wage - First Evidence and Experiences from Other Countries" at the Institute for Employment Research (IAB), the "Key Indicators for Asia and the Pacific Conference 2016" at the Asian Development Bank (ADB), the Korea Labor Institute, and the "Minimum Wage Workshop" at the China Institute For Income Distribution for many helpful comments and suggestions. Carl Lin gratefully acknowledges support from the International Development Research Centre (IDRC) (Grant \#106753).
} 


\section{Introduction}

As part of its endeavor to ensure the provision of basic living standards for its workforce, China accepted the ILO Minimum Wage Fixing Convention in 1984 and issued the 'Enterprises Minimum Wage Regulations' in 1993. In 2004, the government passed new minimum wage regulations, requiring each province to increase its minimum wage at least biannually and increasing the fines for non-compliant companies. The frequency and scale of minimum wage adjustments across the Chinese economy has subsequently increased significantly. In those parts of the country that had implemented a minimum wage by 1996, nominal minimum wage levels increased by $90.42 \%$ until 2004. This was followed by an increase of $178.05 \%$ in the subsequent years until 2012. During our study period from 2000 until 2007, the average national nominal minimum wage rose from 252 RMB (about US\$ 30) to 496 RMB (about US\$ 68). ${ }^{1}$ According to data from the Urban Household Survey used in Fang and Lin (2015), $8.91 \%$ of urban workers and $57.01 \%$ of urban female workers were earning the minimum wage or less between 2004 and 2009. While data on rural migrant workers are scarce, the effect of the minimum wage on this group is estimated to be even larger due to their predominance in low-wage sectors (Wang and Gunderson, 2011).

The expansion of the Chinese minimum wage system has been accompanied by an ongoing controversy regarding the suitability of the policy for the Chinese economy. Proponents argue that it is a necessary means to warrant sufficient living standards for vulnerable workers and that it introduces incentives for companies to upgrade excessively labor intensive production technology, while opponents of the minimum wage policy argue that the policy interferes with the transition to a market economy and that it raises production costs, in turn harming the international competitiveness of Chinese companies (Cooke, 2005; Wang and Gunderson, 2011). Recent research has investigated the effect of the minimum wage on employment and found adverse effects for parts of the Chinese labor force, including female labor (Wang and Gunderson, 2012; Jia, 2014), and workers in non-state owned enterprises and slow-growing regions (Wang and Gunderson, 2011) as well as young adults and low-skilled workers (Fang and Lin, 2015). The effect of the Chinese minimum wage policy on firm investment behavior, which is a direct determinant of long-term company competitiveness, has not been analyzed thus far and the current work aims to make a contribution to fill this gap in the literature. We first analyze whether the cost burden imposed on companies through an increase in minimum wages has harmed company competitiveness in terms of the ability to invest in fixed capital. We then investigate how minimum wages affect the ability of companies to invest in human capital. Investment in human capital is of particular importance in the Chinese case, since it is a key channel to achieve the envisioned skill upgrading in the industrial sector.

The theoretical predictions regarding the effect of an exogenous change in the price of labor due to an increase in the minimum wage differs between standard neoclassical models and non-competitive models of the labor market. Based on standard neoclassical theory, an increase in the price of labor induces firms to substitute away

\footnotetext{
1 The increase between 2000 and 2007 raised the Chinese minimum wage level from merely 2.4 times to 4.3 times the international poverty line of US\$ 1.25 a day (at PPP exchange rates). The increases were also significant relative to the development of local subsistence levels for urban residents. For instance, the subsistence level in Shanghai rose from 280 RMB to 350 RMB, while the minimum wage rose from $435 \mathrm{RMB}$ to $840 \mathrm{RMB}$ during the same time period.
} 
from affected workers. The effect on capital thus depends on the degree of substitutability or complementarity between the two factors of production. Moreover, the cost burden imposed on companies through minimum wages potentially affects capital investments via a scale effect as product prices rise and the level of output drops. The overall effect of an increase in the minimum wage on capital investment therefore depends on the direction and size of the substitution effect and the size of the scale effect.

For the theoretical effect of minimum wage hikes on company training investments, the standard human capital model with competitive labor markets based on Becker (1993) predicts a negative effect on company training expenditures since workers finance their on-the-job training through lower wages. In this case, the introduction of a minimum wage reduces the level of training because it restricts the pay reductions workers can accept to finance the training (Rosen, 1972; Feldstein, 1973).

More recently, non-competitive models of the labor market have been developed in which labor market frictions and asymmetric information lead to a wedge between wages and marginal productivity (Acemoglu and Pischke, 1999). In these models, it can be profitable for a firm to retain a worker despite the increase in wage costs if it can increase worker productivity through investments in capital or training and claim the resulting rents. Contrary to the results from traditional models, a compression of wages through minimum wages may thus induce an increase in fixed capital investments and firm-sponsored training in non-competitive models (Pischke, 2005; Acemoglu and Pischke, 2003). Hybrid models of the labor market that relax the assumption of perfect competition generally predict that the incidence of the minimum wage varies with the degree of competition and the amount of rents that can be allocated.

Currently, there is an ongoing debate reinforced by mixed empirical evidence about which model provides a better fit for empirical data. The present work aims to contribute to this debate by jointly analyzing the effect on the two types of investments and by providing the first piece of evidence on the link between the minimum wage and firm-financed training from a developing economy.

To empirically analyze our research question, we employ the Chinese Annual Census of Industrial Firms (CASIF) data set, which covers the introduction of the new minimum wage regulations in 2004. We include the three years leading up to the reform as well as the four subsequent years during which the magnitude and frequency of minimum wage adjustments across China increased significantly. We then estimate dynamic panel data regressions accounting for the inter-temporal adjustment of fixed capital investments as well as logit and tobit panel data regressions accounting for the incidence of censoring of our dependent variable in the human capital regressions. We find that the minimum wage hikes have caused a decrease in the likelihood of firms to invest in human capital, as well as in the amount of human capital investment per worker.

The rest of this paper is structured as follows. Section 2 reviews the empirical literature on the effects of minimum wages on companies and their investment behavior. Section 3 outlines our research methodology. Section 4 introduces the minimum wage and the firm data employed in this paper. Section 6 provides our results, and section 7 elaborates our research outcomes and concludes the paper. 


\section{Review of the empirical literature}

A monumental body of literature has analyzed the various adjustment channels through which firms absorb the labor cost increase due to minimum wage hikes. In addition to the employment effect, which has been identified for the case of China at least for parts of the labor force, profit reductions are generally considered a key channel of adjustment. Analyzing this topic for another Asian developing economy, Cuong (2013) employs a difference-indifference methodology with propensity score matching and finds no statistically significant effect on firm profits in Vietnam after a minimum wage hike of about $20 \%$ in 2005. Draca et al. (2011) adopt a difference-in-difference approach and show that the introduction of the UK minimum wage in 1999 has reduced firm profitability. Metcalf (2008) concludes that the ability of firms to absorb the increase in labor costs through a reduction in company profits is one of the reasons for an absence of a negative employment effect of the policy in the UK. In a detailed survey study jointly analyzing a range of adjustment channels for local US quick-service restaurants, Hirsch et al. (2011) find that companies adjust through a range of channels, including price increases, profit reductions, lower wage growth for high-pay workers and savings on other cost components. While an extensive exposition of the literature analyzing company effects of minimum wages other than those on firm investment is beyond the scope of this paper, it is important to bear in mind that the ability of companies to absorb the cost increase resulting from minimum wages through other channels also affects the impact on fixed and human capital investments.

Regarding the company fixed capital investment decision, little research has been conducted on this topic thus far and mixed effects have been found in these studies. Rama $(1999,2001)$ finds that doubling the minimum wage in Indonesia during the early 1990s has led to a decrease in employment of $2 \%$ and a decrease in investment of $5 \%$. Based on a model of labor markets with frictions, Pischke (2005) argues that labor market institutions such as unions and minimum wages, which distribute rents to lower skilled workers, raise the incentive for firms to invest in their training and the fixed capital that is associated with their jobs. His empirical analysis based on OECD economies and differences in labor market institutions between Europe and the US roughly supports this theory. A recent report by Riley and Bondibene (2013), however, concludes that the introduction of a national minimum wage in the UK has not affected employment and investment levels.

As explained in the introduction, according to the two different theories on the link between the minimum wage and training, minimum wages could lead to either a reduction in on-the-job training (Rosen, 1972; Feldstein, 1973) or an increase in training (Acemoglu and Pischke, 2003). Interestingly, the empirical evidence on this topic is also mixed which could be due to either the absence of any effect, heterogeneous and potentially offsetting effects or problems related to the measurement of training in the different studies (Neumark and Wascher, 2008). After most of the earlier studies on the topic were plagued by methodological problems, Neumark and Wascher (2001) were the first to control for US state variation in minimum wage levels and inter-state differences in training unrelated to the minimum wage. The authors conclude that the minimum wage has led to a reduction in on-thejob training. Acemoglu and Pischke (2003) criticize the methodology in Neumark and Wascher (2001) for using all young workers as treatment group and arriving at unreasonably high estimates for the size of the negative 
effect. After revising their treatment group to workers with wages below the minimum wage, the authors find no significant effects of the minimum wage. The effect on training expenditures may therefore vary between companies and industries depending on these factors. More recently, Fairris and Pedace (2004) were the first to utilize an employer survey on the incidence of training and found no evidence of a reduction in training hours or the amount of workers covered by staff training. In the only notable study conducted outside the US, Arulampalam et al. (2004) find no evidence that the minimum wage has reduced training and some evidence that it has improved training in the UK.

The inconsistency of previous results, the scarcity of studies from less advanced economies and a frequent focus on the introduction of a uniform national level minimum wage as single policy shift underline the fact that significant scope exists for future research on the effect of minimum wages on firm investment behavior.

\section{Methodology}

\subsection{Measuring the firm-level impact of the minimum wage}

For our empirical analysis of the effect of Chinese minimum wages on the capital investment decision, we construct a panel data set of Chinese firms. Since the new minimum wage regulations were introduced in 2004, we choose the period from 2000 to 2007 as our study period. Including the reform year as well as the pre- and post-reform periods provides significant variation over time in terms of the impact of the minimum wage on individual firms. ${ }^{2}$

A crucial element of our methodology is to identify the firms that are affected by the minimum wage in their county. ${ }^{3}$ As in previous work employing firm data (Draca et al., 2011; Riley and Bondibene, 2013; Cuong, 2013) we make use of average worker wage cost data to measure the extent to which firms are affected by the local minimum wage level. ${ }^{4}$ In particular, we calculate two measures for the exposure to the minimum wage for the firms in our data set: a dichotomous treatment indicator variable and a continuous variable measuring the treatment intensity for those firms whose average wage is below the minimum wage. Using $a w_{i t}$ to denote the logarithm of the average wage level of firm $i$ in year $t$ and $m w_{j t}$ to denote the logarithm of the minimum wage level of county $j$ in period $t$, our treatment dummy variable takes the following values:

$$
\text { treatdum }_{i t}= \begin{cases}0 & \text { if } a w_{i t} \geq m w_{j t} \\ 1 & \text { if } a w_{i t}<m w_{j t}\end{cases}
$$

\footnotetext{
2 Since we need to take first differences for the calculation of our investment variable, our study period includes three pre-policy years and the year when the new minimum wage regulations were implemented (2004) as well as three post-policy years.

3 Compliance with minimum wage regulations is generally problematic in developing countries (see, for example, Rani et al. (2013)). However, Ye et al. (2015)conclude that Chinese firms broadly comply with minimum wage laws. The authors link this to the strict enforcement of labor regulations conducted annually around Chinese New Year. The positive effect of enforcement on compliance in other economies was also found in Gindling et al. (2015) for the case of Costa Rica an Ronconi (2010) for the case of Argentina, whereas the effect was insignificant in a study on South Africa by Bhorat et al. (2012).

4 Because of regional differences in the Chinese minimum wage regulations, the minimum wage level in five jurisdictions also includes social security contributions in addition to wage expenditures. For the calculation of the explanatory variables calculated in this subsection we, therefore, add the contributions for labor and health insurance and pensions incurred by firms located in Beijing, Henan, Jiangsu, Jiangxi and Shanghai to their wage expenditures.
} 
and our continuous variable measuring the treatment intensity for treated firms is as follows: ${ }^{5}$

$$
\text { treatint }_{i t}= \begin{cases}0 & \text { if } a w_{i t} \geq m w_{j t} \\ m w_{j t}-a w_{i t} & \text { if } a w_{i t}<m w_{j t}\end{cases}
$$

Both of our treatment indicators therefore take on the value zero for our control group firms and values greater than zero for treated companies.

A question that arises with these measures of a minimum wage treatment is whether the changes in minimum wages are exogenous. In order to engage with this concern, we provide evidence based on Urban Household Surveys collected by the National Bureau of Statistics of China (NBS) in table A1 in the appendix of this paper showing that minimum wages cannot be explained by local labor market conditions. ${ }^{6}$

\subsection{Fixed capital investments: estimation strategy}

After identifying our treatment and control groups, we proceed to the estimation strategy for our fixed capital and human capital regressions. Our empirical specification for our fixed capital estimations is based on an errorcorrection model of firm investment (Bean, 1981; Bond et al., 2003). In this framework, firms face barriers to instant adjustment of their capital stock and the movement of a firm towards its optimal capital stock can be modeled as a dynamic process. Assuming that the optimal capital stock $\left(K^{*}\right)$ of firm $i$ is a function of its output $(Y)$, unobserved firm-specific effects $\left(\theta_{i}\right)$ and unobserved year-specific effects $\left(\zeta_{t}\right)$, a second-order autoregressive distributed lag model of the dynamic relationship between the realized $(K)$ and the optimal capital stock can be written in error-correction form as: ${ }^{7}$

$$
\Delta k_{i t}=\alpha_{0} \Delta k_{i, t-1}+\alpha_{1} \Delta y_{i t}+\alpha_{2} \Delta y_{i, t-1}+\alpha_{3}\left(k_{i, t-2}-y_{i, t-2}\right)+\theta_{i}+\zeta_{t}+\varepsilon_{i t}
$$

where lower-case Latin letters denote the logarithms of upper-case variables. Similar to the empirical implementation in Chen and Zheng (2008), we also include current and lagged firm profits and debt levels as additional explanatory variables to control for the impact of financial factors on the investment decision. ${ }^{8}$ As a normalization, we divide both of these variables by the capital stock at the beginning of each period. Using $I$ to denote investment rates, treat to denote either our dichotomous or continuous treatment variable and summarizing the above

\footnotetext{
5 An alternative variable measuring the intensity of the minimum wage treatment effect on companies has been proposed by Mayneris et al. (2014). Implementing our regressions with their explanatory variable does not qualitatively alter our treatment intensity results, and we do not report the alternative results.

6 In particular, we use a panel regression model with year and county fixed effects and define the dependent variable as the normalized minimum-to-average wage ratio or non-normalized minimum wages, and include GDP per capita, the youth unemployment rate, CPI, and FDI as the independent variables. We also replace the youth unemployment rate with the general unemployment level (in log form) to see if the results change. We report these results in appendix table A1 on page 26. In specifications (1) to (3) of table A1, the results show that all estimates are statistically insignificant which suggests that labor market conditions cannot predict minimum wage changes. In addition, specifications (4) to (6) use the general unemployment level instead of the youth unemployment rate. The results also show that all estimates, except for GDP per capita, are statistically insignificant.

7 We also implemented a third-order autoregressive model to check the robustness of our results. This did not affect the significance of our error-correction terms and our explanatory variables.

8 A difference to the implementations in Bond et al. (2003) and Chen and Zheng (2008) is that we resort to operating profits because cash flow data have only been included in the CASIF data set since 2003.
} 
coefficients $(\boldsymbol{\alpha})$ and variables $\left(\boldsymbol{x}_{i t}\right)$ in matrix notation, we obtain our fixed capital investment regression equation as:

$$
I_{i t}=\boldsymbol{\alpha}^{\prime} \boldsymbol{x}_{i t}+\beta \text { treat }_{i t-1}+\varepsilon_{i t}
$$

Special attention needs to be given to the appropriate estimation strategy for this equation. In particular, estimating this dynamic process via an OLS estimation of the levels or by estimating the within-group fixedeffect transformation of the above equation would both yield biased estimators due to the positive correlation of regressors with the error term (Nickell, 1981). An estimator that yields unbiased and consistent results for such an autoregressive process with possibly endogenous regressors in a situation with a large number of cross-sectional units and few time periods as in our case is the first-difference Generalized Method of Moments (GMM) estimator developed by Arellano and Bond (1991). Their estimation procedure first removes the time-invariant firm-specific effects through first differencing and then derives instruments to be utilized in the estimation from lagged values of the regressors. Since the problem of instrument proliferation is negligible in our case, we adopt the most general specification and employ all available higher-order lagged values of our right hand side variables in equation 3 as well as of our financial variables as instruments. ${ }^{9}$ The consistency and unbiasedness of our GMM estimator relies on the assumptions that serial correlation in the error term is absent and the instruments are valid. ${ }^{10}$ We implement the Sargan/Hansen test for joint instrument validity and autocorrelation tests proposed in Arellano and Bond (1991) to ascertain the validity of both assumptions.

\subsection{Human capital investments: estimation strategy}

For our analysis of the effect of minimum wage hikes on the human capital investment decision, we estimate the following regression:

$$
H_{i t}=\gamma^{\prime} z_{i t-1}+\delta \text { treat }_{i t-1}+\varepsilon_{i t}
$$

where our dependent variable $H$ is investments in human capital measured as training expenditures per worker, treat is either our dichotomous or our continuous treatment variable, $z$ is a vector of control variables and $\varepsilon$ is a stochastic error term. As in previous literature analyzing the effect of the minimum wage on firm training expenditures (Arulampalam et al., 2004; Fairris and Pedace, 2004), our firm level controls essentially aim to capture firm level heterogeneity by including variables such as workforce size, wages, labor productivity. These controls are measured in the previous period to ensure the exogeneity of these variables. ${ }^{11}$ We also include dummy variables for state or foreign ownership and exporter status of a firm. These variables take on zero values for

\footnotetext{
9 Roodman (2009) provides a detailed analysis of the problems arising from employing too many instruments in GMM estimation. The rule of thumb in empirical GMM estimations is that the number of instruments should be less than the number of cross-sectional units. In our case, we employ a maximum of 44 instruments, and the minimum number of cross-sectional units included in the GMM regressions for the smallest subset of firms is 8827 .

10 Note that first order autocorrelation of the differenced error terms is expected because of the common element of first-differenced error terms in adjacent periods.

11 Larger firms are generally more able to provide workforce training, for example due to economies of scale. Labor productivity and wages reflect the initial skill level of the workforce and affect the returns to human capital investments.
} 
non-state owned companies, local companies and non-exporters, respectively. ${ }^{12}$

Because of the censoring of our human capital investment variable, least squares estimation of human capital models would result in biased estimators (see, for example, Greene (2003)). We therefore first estimate a logit model with a binary dependent variable measuring the presence or absence of human capital investment in order to analyze the impact of the minimum wage on the likelihood of firms to undertake human capital investments for those firms that have invested in human capital in some periods and have not invested in others. Secondly, we then estimate tobit models with human capital investment rates as the dependent variable and analyze the effect of the minimum wage on the level of human capital investment rates of all firms. In our logit regressions for human capital investment, we are able to control for firm level fixed effects. For the tobit model panel data estimator, no estimator with individual fixed effects exists that allows for conditioning on covariates. In our tobit regressions we thus control for industry-level fixed effects at the two-digit level and mimic individual effects by including a range of variables reflecting the staff structure of companies. These variables have only been investigated in the 2004 version of the CASIF survey, and we include those values for each firm in all time periods covered. In particular, we include a dummy variable for the presence of a workers' union and calculate the shares of technical staff, staff holding a university degree and the share of female workers.

\section{Data set and statistics of key variables}

\subsection{Data sources and data editing}

The first type of data used in this section are the minimum wage data that have been collected from the websites of local governments across China. In particular, we obtain the precise dates of minimum wages amendments and minimum wage levels for a total of 2,606 Chinese counties and calculate the respective weighted annual average minimum wage in each of these geographical units. ${ }^{13}$ The development of real minimum wages over time is shown in table 1. As mentioned in the introduction, Chinese minimum wages have increased rapidly, especially after the introduction of the new regulations in 2004. From an empirical perspective, another interesting feature of the Chinese system of minimum wages is that it has not only developed rapidly over time, but the levels also differ significantly between provinces and within provinces between different counties. For example, at the end of our study period in 2007, the nominal minimum wage in Shanghai was at 840 RMB, approximately 2.6 times the level of $320 \mathrm{RMB}$ in the less developed areas of Gansu Province. At the same time the minimum wage level in Lanzhou, the capital of Gansu Province, was already at 430 RMB, hence approximately 34\% above the lowest level in the same province. Liaoning Province can be credited with the most complex minimum wage system and its nominal

\footnotetext{
12 Our definition of state-owned companies includes all state-owned and state-holding companies, i.e., all companies in which the state holds a majority. This is the broad definition adopted by the Chinese National Bureau of Statistics. Local non-state owned companies include collectively owned and private companies. For foreign ownership, we also adopt the Chinese definition and consider companies with a foreign capital share of at least $25 \%$ as foreign invested.

13 In this paper, we collectively refer to counties and prefecture level cities as "counties". These administrative units included in our analysis are located across all of the Chinese provincial level administrative divisions, i.e. the 22 provinces, five autonomous regions and four municipalities, to which we collectively refer as "provinces".
} 
minimum wages ranged from 420 to $700 \mathrm{RMB}$ in the final year of our study.

The second data source employed in this section is the CASIF, which has been conducted by the NBS. The survey includes data from all state-owned firms as well as all non-state owned industrial firms with a revenue of more than 5 million RMB (about US\$ 680,000). ${ }^{14}$ This firm level data set enables us to calculate our dependent and explanatory variables as well as a range of control variables including sales volume, employment levels and industry classifications. In order to construct a panel data set, our main method to match companies over time is to utilize their registration ID. Since some company IDs change over time and a few IDs occur for multiple firms, we adopt the procedure proposed in Brandt et al. (2012) and also utilize other firm information such as the names of legal firm representatives, office phone numbers and addresses to merge firms over time. ${ }^{15}$ Disaggregated deflators for the prices of output and capital at the industry and province level have been collected from various editions of the China statistical yearbook (NBS, 2008). ${ }^{16}$ We deflate all monetary values in our data set to the price level in year 2000, which is the first year included in our data set. We then clean our data set from reporting errors and typos in the construction of the data base by deleting all firms with zero or negative values for one of the following variables: capital stock, number of employees, output or sales volume and wage expenditures. As a final logical consistency check, we also exclude observations reporting a depreciation in the current period that is higher than the capital stock in the previous period. As in other work analyzing the effects of policies on company investments, we exclude companies with fixed capital investment rates greater than one from our analysis to prevent outliers from contaminating our results. Our firm data set is then merged with our minimum wage data set through a six-digit administrative division code.

\subsection{Dependent variables, explanatory variable and descriptive statistics}

We then proceed to the calculation of our wage variable and our dependent variables. We calculate the average wage per worker in year $t$ as firm level wage expenditures divided by the average number of staff employed throughout the year. For the calculation of our fixed capital investment variable, we employ the perpetual inventory method and calculate firm level investment rates as the change in the firm capital stock plus depreciation, divided by the capital stock in the previous period. Firm investment rates in human capital are calculated as the amount of training expenditures divided by the number of employees. ${ }^{17}$ Our final data set consists of 1,118,675 firm-year observations from the seven year period between 2001 and $2007 .{ }^{18}$

Table 2 presents the key statistical properties of our dependent variables as well as the ratio of the minimum wage to the firm level average wage for each year in our data set. The steady growth in size and number of

\footnotetext{
14 The China national economic census conducted by the NBS in 2004 allows for a comparison with the 2004 CASIF data set. The firms included in the 2004 CASIF survey constitute approximately $20.3 \%$ of all Chinese firms included in the economic census. They contribute approximately $90.7 \%$ of Chinese industrial output, hence covering almost all of Chinese industrial activity.

15 Among the observations that could be matched to the previous year, we were able to match $95.93 \%$ based on company IDs, and the remaining $4.07 \%$ were matched using other firm information.

16 Upward et al. (2013) have collected the deflators from NBS and make them available on their website. Since we also need deflators from 1999, we supplement their data set with deflators obtained directly from national yearbooks.

17 The training expenditures variable refers to a range of expenditures related to staff training, including training in new technologies, continuing staff education and the purchase of teaching equipment.

18 Observations from the years 1999 and 2000 are only used as lagged values in our GMM estimations.
} 
Chinese companies results in the successive inclusion of additional firms in our database, and the number of annual observations increases from 101,979 observations in 2001 to 237,363 observations in 2007. The minimum wage level amounts to between approximately $50 \%$ and $60 \%$ of the company-level average wage in most years covered. In the reform year of 2004 and the first year thereafter, the minimum wage rises to more than $60 \%$ of average wages until companies adjust their wage levels and the ratio drops to a level below the pre-reform period. Average training expenditures per worker rise from $58 \mathrm{RMB}$ in the first year to a level of about $88 \mathrm{RMB}$ towards the end of our study period. Differences between firms are large for this variable and firms with high investment expenditures in human capital spend more than 1402 RMB per worker. Moreover, about 58.9\% of our companyyear observations report zero investment in human capital, hence necessitating the estimation of human capital investment regressions through logit and tobit models. The variable with the highest variation both over time and between firms is our fixed capital investment rate. Starting from 7.4\% in 2001, it rises to approximately $12.0 \%$ in 2005 before dropping again to a level of $9.9 \%$ in the final year of our analysis. All three indicators exhibit significant variation both over time and between firms.

\section{Wage growth comparison of firms in treated and control group}

The key underlying assumption of the theoretical link between minimum wage regulations and company development indicators is that a minimum wage increase drives up company wage expenditures for affected companies. We briefly investigate the link between the two variables by analyzing the difference in subsequent wage growth between treated and non-treated companies. To control for the difference in average wage levels between treated and non-treated companies, we split our companies into fifty quantiles according to their wage level and then compare subsequent changes in the log wage for the two groups in order to analyze whether they have been affected differently. The results displayed in table 3 show that wage growth of treated companies is more than twice as high as wage growth of the non-treated group in the lowest quantiles. As we move up towards higher quantiles in the wage distribution, wage growth of the treated group amounts to more than four times the wage growth of non-treated companies. Relative to prevailing profit levels, the average wage bill of the affected firms increased by an additional $33.8 \%$. We also regress subsequent average wage growth on minimum wage growth for treated and non-treated companies separately to compare the intensity of the impact of subsequent minimum wage growth on average wage growth. The coefficients of the subsequent wage growth variable are at least twice as high for treated companies compared to non-treated companies across different wage quantiles. The assumption therefore proves valid for our data set, and our instrument is an adequate tool to identify affected companies.

As pointed out by Ye et al. (2015), compliance rates with the minimum wage policy differ between companies depending on the ownership structure of a firm. ${ }^{19}$ We therefore also investigate whether the impact of the minimum

\footnotetext{
19 According to Ye et al. (2015), compliance rates are lowest for Hong Kong, Macao and Taiwan invested companies, and 9.4\% of workers for this company type earn below the minimum wage. Compliance rates for non-state domestic companies and state-owned companies are $2.9 \%$ and $2.8 \%$, respectively. Foreign owned companies are the most compliant, and only $2.3 \%$ of their workers earn less than the minimum wage.
} 
wage treatment differs between different firm types. In particular, we distinguish between local non-state-owned firms, state-owned firms, and firms with investors from Hong Kong, Macao or Taiwan as well as foreign invested firms. As displayed in table 4, the four company types differ markedly in terms of their wage growth even within the same wage quantile. Foreign firms exhibit the highest wage growth, while wage growth in the state-owned sector is the lowest among the four at approximately one quarter of foreign firm wage growth. The four company groups, however, hardly differ in terms of the treatment effect on wage growth and wage growth among treated companies is higher in almost all quantiles for all four company types. Despite the differences in policy compliance rates and wage growth, the treatment effect on wage growth therefore occurs for all four company types.

\section{Fixed and human capital investment regression results}

\subsection{Employment regression results}

To develop a more more detailed account of how the Chinese minimum wage has affected investment levels, we first implement panel data regressions estimating the effect of the minimum wage on firm-level employment levels. To this end, we regress firm level employment in the current period $\left(L_{i t}\right)$ on our treatment indicators, as well as on employment and a number of control variables $\left(\boldsymbol{z}_{i t-1}\right)$ from the previous period. We also include controls for industries, cities and year-effects $\left(\mu_{c, k}\right)$. The regression specification, which is similar to the prespecified research design adopted in Neumark (2001) and Campolieti et al. (2006), takes the following form:

$$
L_{i t}=\boldsymbol{\alpha}^{\prime} z_{i t-1}+\beta L_{i t-1}+\gamma \mu_{c, k}+\delta \text { treat }_{i t-1}+\varepsilon_{i t}
$$

Our employment regression results shown in table 5 indicate that the minimum wage has exerted a negative impact on firm-level employment levels. Huang et al. (2014) also find this negative effect for low-wage firms in the Chinese economy, which is the group of firms most similar to those in our treatment group. The negative effects from our firm-level analysis also reflect the negative employment effects found in studies using individual micro data (Jia, 2014; Fang and Lin, 2015), and those found based on provincial economic data (Wang and Gunderson, 2011, 2012).

\subsection{Basic investment regression results}

We then move on to the investment regressions, which is the main focus of our analysis. The first column in table 6 displays the regression results of our fixed capital investment models with our dummy treatment indicator as explanatory variable, and the second column presents our fixed capital investment results with our treatment intensity indicator as explanatory variable. For both of our explanatory variables, we find no effect of the minimum wage on fixed capital investments.

Regarding the coefficient of our control variables, the change in the logarithm of output correlates positively and 
significantly with fixed capital investment, hence confirming the predictions of the accelerator model of investment. The error-correction term is negative and significant, hence confirming error-correction behavior of firms towards their optimal capital stock. The financial variables are insignificant, which was also previously found in Chen and Zheng (2008) for companies in most Chinese regions.

Table 7 displays the logit and tobit regression results of our human capital investment regressions with the dummy treatment indicator as explanatory variable (Models 3 and 5) and our treatment intensity indicator as explanatory variable (Models 4 and 6). ${ }^{20}$ In our logit estimations, we omit the firms that do not display any variation in the dependent variable, i.e. the ones that either invest in human capital in every period or never invest in human capital. Our logit results for both explanatory variables indicate that the total effect on the likelihood of firms to invest in human capital is negative and significant. For our tobit regressions, we can retain all firms and all censored and uncensored firm-year observations. ${ }^{21}$ Our tobit regressions with two alternative explanatory variables unequivocally demonstrate that the minimum wage has reduced the amount of training expenditures incurred per worker for Chinese companies.

Some interesting findings also emerge from the results of our human capital regression covariates. The human capital stock and firm size both correlate positively with human capital investments. Foreign-owned companies in the Chinese market are characterized by lower investment rates than local companies, while exporters are more likely to invest in human capital. The establishment of a workers' union as well as the shares of technical staff and university graduates in total staff all correlate positively with human capital investment rates, whereas the share of female workers correlates negatively with human capital investment rates.

\subsection{Investment regression results for different firm ownership types}

In this subsection, we again split our firms into groups according to the four different ownership types introduced in the previous section and implement our fixed and human capital investment regressions separately for each group. ${ }^{22}$ For our fixed capital investment regressions shown in table 8 , the results do not differ between company types. ${ }^{23}$ Error-correction behavior and the output effect predicted by the accelerator model of investment are confirmed in all regressions except for the state-owned group.

In contrast to the fixed capital investment regression results, the results of our human capital investment regressions are remarkably homogeneous across local private owned, state-owned and Hong Kong/Macao/Taiwan owned firms and mirror the results of our basic regression results. The logit model treatment variable is negative

\footnotetext{
20 We also conduct a robustness check by using training per log output as an alternative dependent variable measuring training intensity, and our results did not change qualitatively.

21 The sample for these regressions includes 419,487 censored and 337,024 uncensored observations.

22 To make the exposition more concise, we only report the results of our dummy treatment variable regressions in this subsection. The results for our treatment intensity variable are in line with the results for the treatment dummy variable, i.e. both either insignificant or significant with the same sign.

23 To simplify the search for the optimal set of instruments, we drop the insignificant financial variables and implement the basic errorcorrection model shown in equation 3. Our strategy for selecting the optimal number of instruments is to start from the specification implemented for our complete sample. If this specification fails the Hansen test or the second order autocorrelation test for any of our sub-samples, we move on towards deeper lags; see Guariglia et al. (2011). The number of instruments employed therefore differs between different sub-samples of firms.
} 
and significant for all non-foreign firms. The respective coefficient in our tobit model is negative and significant for the four ownership types. The minimum wage policy therefore negatively affects both the likelihood of firms to invest in human capital and human capital investment rates.

\subsection{Robustness checks: evidence based on an alternative treatment indicator}

In this subsection, we employ data on the staff structure of firms that has been uniquely investigated as part of the 2004 CASIF data set and calculate an alternative measure to our initial treatment indicator based on the relationship between average wages at the firm level and county-level minimum wage standards. Our motivation is that the average wage may correlate insufficiently with the percentage of affected people in a firm due to differences in within-firm wage distributions.

We therefore revise our treatment indicator as follows. According to previous analysis on Chinese minimum wages conducted by Fang and Lin (2015), female workers are about six times as likely to receive the minimum wage or less as the average worker. Moreover, workers whose highest educational attainment is a middle school degree or less are about seven times as likely to receive the minimum wage as staff with a college degree. ${ }^{24}$ In this subsection, we therefore exploit data on the share of female workers with a middle school degree or less calculated for each firm to obtain an alternative measure of firm exposure to the minimum wage. In particular, we use $f m s_{i, 2004}$ to denote the share of female staff with a middle school degree or less and $f m s 90 p, 2004$ to denote the 90th percentile of this ratio in the distribution of all firms. Based on these two variables we identify our treatment group as:

$$
\text { treatdum }_{i, 2004}= \begin{cases}0 & \text { if } f m s_{i, 2004}<f m s_{90 p, 2004} \\ 1 & \text { if } f m s_{i, 2004} \geq f m s_{90 p, 2004}\end{cases}
$$

We also calculate a measure for the minimum wage treatment intensity as follows:

$$
\text { treatint }_{i, 2004}= \begin{cases}0 & \text { if } f m s_{i, 2004}<f m s_{90 p, 2004} \\ \Delta m w_{j, 2005-2003} \times \text { treat }_{i, 2004} & \text { if } f m s_{i, 2004} \geq f m s_{90 p, 2004}\end{cases}
$$

For this cross-section specification, we calculate our dependent variables as the two-period average difference in our outcome variables $\left(\Delta Y_{i, 2005-2003}\right)$. We control for a range of firm characteristics measured in the initial year included in this part of the analysis $\left(z_{i, 2003}\right)$, such as the average wage, labor productivity, staff size and dummy variables for state ownership, foreign ownership, exporter status, as well as for industry and city dummy variables $\left(\mu_{c, k}\right)$. This model, which is analogous to the model implemented in Mayneris et al. (2014), can be summarized as follows:

$$
\Delta Y_{i, 2005-2003}=\alpha_{\text {treat }}, 2004+\boldsymbol{\beta}^{\prime} z_{i, 2003}+\gamma \mu_{c, k}+\varepsilon_{i, 2005}
$$

\footnotetext{
24 The precise percentages of workers earning no more than the minimum wage calculated based on the Urban Household Survey employed in the study are: $67.01 \%$ of female workers compared to $8.91 \%$ for all workers, $25.16 \%$ of workers with no more than an elementary school degree, and $15.43 \%$ of workers with a middle school degree compared to, for example, only $2.99 \%$ of workers with a college degree; see table 3 in Fang and Lin (2015).
} 
The results from these regressions are displayed in table 10 and confirm our previous findings that firms have not altered their fixed capital investment behavior, but have decreased their human capital investments in response to the minimum wage.

\section{Conclusions and discussion}

During the past two decades, China has implemented a complex system of minimum wages across the country. Consequently, minimum wages have risen sharply, especially since the introduction of the new minimum wage regulations in 2004. In this paper, we focus on the potential adverse effects on firm behavior due to the Chinese minimum wage policy by empirically analysing the effect on the firm investment decision in a panel data set of all state-owned and all above-scale non-state-owned Chinese firms. According to standard economic theory, an increase in labor costs through minimum wage adjustments imposes a negative scale effect on companies, in turn leading to a reduction in fixed capital investment. Standard models of human capital theory also predict a negative effect on human capital investment since a wage floor reduces the ability of employees to accept wage reductions in order to enable companies to finance worker training. On the other hand, models of non-competitive labor markets generally predict that company fixed and human capital investments associated with affected labor groups will rise in the face of an exogenous increase in labor costs.

Our empirical results indicate that the Chinese minimum wage policy has indeed reduced firm investment in human capital, while it has not led to a change in fixed capital investment rates. In addition, we find a negative effect on firm-level employment levels, thus a twofold negative overall effect on the factor labor that is in line with the predictions of neoclassical models of the labor market. An important detail of our analysis is the finding that the ownership structure of a firm matters as the likelihood that foreign firms engage in human capital investments has not decreased in response to the policy. A limitation of our study is that the panel data set of Chinese firms employed in our study does not cover small firms. Minimum wages may affect these firms differently and may also impact the dynamic evolution of the firms that survive in an industry.

Overall, the negative effect on human capital investments is an important consequence of the minimum wage policy, and the competitiveness of Chinese companies may suffer as a consequence of the minimum wage regulations. The decrease in human capital investment rates is likely to reduce labor productivity growth, and further adverse effects on the labor market may occur in the long term. 


\section{References}

Acemoglu, D. and Pischke, J.-S. (1999) The structure of wages and investment in general training, Journal of Political Economy, 107, 539-572.

Acemoglu, D. and Pischke, J.-S. (2003) Minimum wages and on-the-job training, Research in Labor Economics, 22, 159-202.

Arellano, M. and Bond, S. (1991) Some tests of specification for panel data: Monte carlo evidence and an application to employment equations, The Review of Economic Studies, 58, 277-297.

Arulampalam, W., Booth, A. L. and Bryan, M. L. (2004) Training and the new minimum wage, The Economic Journal, 114, C87-C94.

Bean, C. (1981) An econometric model of manufacturing investment in the UK, Economic Journal, 91, $106-21$.

Becker, G. (1993) Human capital: a theoretical and empirical analysis, with special reference to education, The University of Chicago Press, Chicago.

Bhorat, H., Kanbur, R. and Mayet, N. (2012) Estimating the causal effect of enforcement on minimum wage compliance: The case of South Africa, Review of Development Economics, 16, 608-623.

Bond, S., Elston, J. A., Mairesse, J. and Mulkay, B. (2003) Financial factors and investment in Belgium, France, Germany, and the United Kingdom: A comparison using company panel data, The Review of Economics and Statistics, 85, 153-165.

Brandt, L., Biesebroeck, J. V. and Zhang, Y. (2012) Creative accounting or creative destruction? firm-level productivity growth in Chinese manufacturing, Journal of Development Economics, 97, 339-351.

Campolieti, M., Gunderson, M. and Riddell, C. (2006) Minimum wage impacts from a prespecified research design: Canada 1981â-1997, Industrial Relations: A Journal of Economy and Society, 45, 195-216.

Chen, M. and Zheng, Y. (2008) China's regional disparity and its policy responses, China \& World Economy, 16, $16-32$.

Cooke, F. L. (2005) HRM, work and employment in China, Routledge, London.

Cuong, N. V. (2013) Do minimum wage increases matter to firm profitability? The case of Vietnam, Journal of International Development, forthcoming.

Draca, M., Machin, S. and Van Reenen, J. (2011) Minimum wages and firm profitability, American Economic Journal: Applied Economics, 3, 129-51.

Fairris, D. and Pedace, R. (2004) The impact of minimum wages on job training: An empirical exploration with establishment data, Southern Economic Journal, 70, 566-583.

Fang, T. and Lin, C. (2015) Minimum wages and employment in China, IZA Journal of Labor Policy, 4, 1-30.

Feldstein, M. (1973) The economics of the new unemployment, Public Interest, 33, 3-42.

Gindling, T. H., Mossaad, N. and Trejos, J. D. (2015) The consequences of increased enforcement of legal minimum wages in a developing country - an evaluation of the impact of the campaña nacional de salarios mínimos in Costa Rica, Industrial and Labor Relations Review, 68, 666-707. 
Greene, W. (2003) Econometric analysis, Prentice Hall, N.J.

Guariglia, A., Liu, X. and Song, L. (2011) Internal finance and growth: Microeconometric evidence on Chinese firms, Journal of Development Economics, 96, 79 - 94.

Hirsch, B. T., Kaufman, B. E. and Zelenska, Y. (2011) Minimum wage channels of adjustment, IZA Discussion Paper No. 6132.

Huang, Y., Loungani, P. and Wang, G. (2014) Minimum wages and firm employment: evidence from China, Federal Reserve Bank of Dallas. Globalization and Monetary Policy Institute Working Paper No. 173.

Jia, P. (2014) Employment and working hour effects of minimum wage increase: Evidence from China, China \& World Economy, 22, 61-80.

Mayneris, F., Poncet, S. and Zhang, T. (2014) The cleansing effect of minimum wage, paper presented at the Conference on Industrial Upgrading and Urbanization, Stockholm China Economic Research Institute, Stockholm.

Metcalf, D. (2008) Why has the British national minimum wage had little or no impact on employment?, Journal of Industrial Relations, 50, 489-512.

National Bureau of Statistics of China (2008) China Statistical Yearbook, China Statistics Press, Beijing.

Neumark, D. (2001) The employment effects of minimum wages: Evidence from a prespecified research design the employment effects of minimum wages, Industrial Relations: A Journal of Economy and Society, 40, 121-144.

Neumark, D. and Wascher, W. L. (2001) Minimum wages and training revisited, Journal of Labor Economics, 19, $563-595$.

Neumark, D. and Wascher, W. L. (2008) Minimum wages, MIT Press, Cambridge, Mass.

Nickell, S. (1981) Biases in dynamic models with fixed effects, Econometrica, 49, 1417-1426.

Pischke, J.-S. (2005) Labor market institutions, wages, and investment: Review and implications, CESifo Economic Studies, 51, 47-75.

Rama, M. (1999) The consequences of doubling the minimum wage: The case of Indonesia, Policy Research Working Paper 1643, The World Bank.

Rama, M. (2001) The consequences of doubling the minimum wage: The case of Indonesia, Industrial and Labor Relations Review, 54, 864-881.

Rani, U., Belser, P., Oelz, M. and Ranjbar, S. (2013) Minimum wage coverage and compliance in developing countries, International Labour Review, 152, 381-410.

Riley, R. and Bondibene, C. R. (2013) The impact of the national minimum wage on firm behaviour during recession, Research Report for the Low Pay Commission, Unpublished.

Ronconi, L. (2010) Enforcement and compliance with labor regulations in Argentina, Industrial and Labor Relations Review, 63, 719-736.

Roodman, D. (2009) A note on the theme of too many instruments, Oxford Bulletin of Economics and Statistics, 71, 135-158.

Rosen, S. (1972) Learning and experience in the labor market, The Journal of Human Resources, 7, 326-342. 
Upward, R., Wang, Z. and Zheng, J. (2013) Weighing China's export basket: The domestic content and technology intensity of chinese exports, Journal of Comparative Economics, 41, 527-543.

Wang, J. and Gunderson, M. (2011) Minimum wage impacts in China: Estimates from a prespecified research design, 2000-2007, Contemporary Economic Policy, 29, 392-406.

Wang, J. and Gunderson, M. (2012) Minimum wage effects on employment and wages: dif-in-dif estimates from Eastern China, International Journal of Manpower, 33, 860-876.

Ye, L., Gindling, T. and Li, S. (2015) Compliance with legal minimum wages and overtime pay regulations in China, IZA Journal of Labor \& Development, 4, 16. 
Table 1: Chinese provincial minimum wages over time (in RMB per month)

\begin{tabular}{|c|c|c|c|c|c|c|c|c|}
\hline Province & 2000 & 2001 & 2002 & 2003 & 2004 & 2005 & 2006 & 2007 \\
\hline \multicolumn{9}{|l|}{ East } \\
\hline Beijing & 406.0 & 410.8 & 444.5 & 458.2 & 507.6 & 541.2 & 581.8 & 638.0 \\
\hline Fujian & 259.8 & 282.6 & 302.6 & 313.9 & 314.6 & 343.4 & 406.6 & 463.0 \\
\hline Guangdong & 338.6 & 350.7 & 362.7 & 371.2 & 365.0 & 417.4 & 447.9 & 488.9 \\
\hline Hainan & 277.5 & 308.6 & 348.9 & 348.4 & 361.2 & 383.1 & 415.2 & 434.9 \\
\hline Hebei & 242.5 & 241.3 & 283.9 & 285.9 & 354.4 & 426.9 & 424.8 & 419.9 \\
\hline Jiangsu & 275.8 & 301.0 & 319.6 & 360.8 & 404.3 & 426.2 & 488.5 & 535.6 \\
\hline Shandong & 264.1 & 287.0 & 325.4 & 347.5 & 335.3 & 408.9 & 416.1 & 430.8 \\
\hline Shanghai & 424.8 & 467.5 & 510.0 & 549.4 & 586.5 & 638.8 & 676.2 & 720.1 \\
\hline Tianjin & 347.3 & 394.1 & 425.0 & 449.0 & 481.2 & 524.6 & 600.6 & 641.1 \\
\hline Zhejiang & 372.5 & 398.6 & 410.6 & 423.8 & 468.8 & 525.9 & 578.6 & 625.5 \\
\hline \multicolumn{9}{|l|}{ Northeast } \\
\hline Heilongjiang & 262.6 & 260.5 & 262.4 & 284.9 & 274.4 & 271.2 & 353.0 & 377.4 \\
\hline Jilin & 231.6 & 228.6 & 251.8 & 278.3 & 303.0 & 298.5 & 369.7 & 514.6 \\
\hline Liaoning & 265.7 & 268.7 & 278.4 & 273.8 & 276.1 & 346.1 & 378.1 & 424.3 \\
\hline \multicolumn{9}{|l|}{ Central } \\
\hline Anhui & 220.1 & 272.9 & 290.7 & 300.5 & 293.8 & 308.3 & 321.5 & 361.0 \\
\hline Henan & 209.8 & 208.4 & 208.2 & 216.5 & 238.3 & 253.3 & 309.0 & 325.7 \\
\hline Hubei & 203.7 & 203.1 & 276.8 & 270.8 & 258.1 & 289.7 & 293.1 & 351.8 \\
\hline Hunan & 231.3 & 252.4 & 280.9 & 311.6 & 326.1 & 345.7 & 373.2 & 392.1 \\
\hline Jiangxi & 214.1 & 220.3 & 220.1 & 218.4 & 243.1 & 300.6 & 301.7 & 392.6 \\
\hline Shanxi & 225.9 & 226.3 & 270.7 & 265.9 & 387.1 & 418.6 & 417.1 & 431.6 \\
\hline \multicolumn{9}{|l|}{ West } \\
\hline Chongqing & 246.2 & 257.5 & 279.0 & 287.9 & 322.9 & 343.6 & 373.9 & 431.1 \\
\hline Gansu & 227.6 & 235.2 & 235.2 & 232.7 & 283.2 & 278.4 & 291.0 & 304.2 \\
\hline Guangxi & 172.0 & 223.7 & 313.0 & 309.7 & 313.4 & 354.8 & 359.0 & 366.9 \\
\hline Guizhou & 213.4 & 209.6 & 238.8 & 290.3 & 291.1 & 323.4 & 349.3 & 430.5 \\
\hline Inner Mongolia & 238.1 & 236.7 & 251.2 & 289.9 & 324.5 & 358.6 & 363.2 & 375.5 \\
\hline Ningxia & 264.2 & 264.0 & 311.1 & 306.1 & 321.3 & 319.0 & 362.7 & 377.4 \\
\hline Qinghai & 236.3 & 230.3 & 225.1 & 220.7 & 238.8 & 311.2 & 352.7 & 374.3 \\
\hline Shaanxi & 213.0 & 225.7 & 273.3 & 269.2 & 262.4 & 335.4 & 420.2 & 413.8 \\
\hline Sichuan & 160.9 & 161.4 & 211.0 & 253.4 & 276.6 & 318.1 & 291.4 & 366.0 \\
\hline Xinjiang & 257.7 & 258.4 & 292.0 & 290.8 & 306.6 & 316.4 & 345.1 & 401.1 \\
\hline Yunnan & 233.1 & 235.2 & 261.2 & 283.2 & 286.5 & 339.6 & 367.3 & 379.0 \\
\hline
\end{tabular}

Notes: Minimum wages have been calculated as time-weighted and population-weighted average values based on county level minimum wage data. Values have been deflated to the price level in year 2000. 
Table 2: Summary statistics for key variables over time

\begin{tabular}{|c|c|c|c|c|c|c|}
\hline & Variable & Mean & Std. Dev. & Min. & Max. & Observations \\
\hline \multirow{3}{*}{ 휴 } & Investment rate & 0.074 & 0.274 & -0.855 & 1 & 93393 \\
\hline & Training / labor & 0.058 & 0.131 & 0 & 1.401 & 101979 \\
\hline & Min. Wage / Avg. Wage & 0.556 & 0.324 & 0.04 & 3.846 & 101979 \\
\hline \multirow{3}{*}{ ָํㅇ } & Investment rate & 0.088 & 0.278 & -0.855 & 1 & 105964 \\
\hline & Training / labor & 0.066 & 0.143 & 0 & 1.401 & 117230 \\
\hline & Min. Wage / Avg. Wage & 0.560 & 0.329 & 0.039 & 3.839 & 117230 \\
\hline \multirow{3}{*}{ ஜ̊ } & Investment rate & 0.083 & 0.288 & -0.855 & 1 & 112142 \\
\hline & Training / labor & 0.070 & 0.149 & 0 & 1.401 & 125674 \\
\hline & Min. Wage / Avg. Wage & 0.547 & 0.325 & 0.039 & 4.39 & 125674 \\
\hline \multirow{3}{*}{ 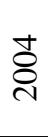 } & Investment rate & 0.051 & 0.313 & -0.855 & 1 & 115069 \\
\hline & Training / labor & 0.066 & 0.135 & 0 & 1.399 & 130211 \\
\hline & Min. Wage / Avg. Wage & 0.716 & 0.364 & 0.042 & 4.59 & 130211 \\
\hline \multirow{3}{*}{ ஜ̊ } & Investment rate & 0.120 & 0.297 & -0.855 & 1 & 170285 \\
\hline & Training / labor & 0.079 & 0.163 & 0 & 1.401 & 195597 \\
\hline & Min. Wage / Avg. Wage & 0.521 & 0.229 & 0.039 & 4.79 & 195597 \\
\hline \multirow{3}{*}{ ঠৃ } & Investment rate & 0.117 & 0.295 & -0.855 & 1 & 186230 \\
\hline & Training / labor & 0.085 & 0.171 & 0 & 1.401 & 210621 \\
\hline & Min. Wage / Avg. Wage & 0.507 & 0.222 & 0.035 & 4.809 & 210621 \\
\hline \multirow{3}{*}{ 용 } & Investment rate & 0.099 & 0.293 & -0.855 & 1 & 211098 \\
\hline & Training / labor & 0.088 & 0.179 & 0 & 1.402 & 237363 \\
\hline & Min. Wage / Avg. Wage & 0.492 & 0.223 & 0.044 & 4.995 & 237363 \\
\hline
\end{tabular}

Notes: Data have been deflated to the price level in year 2000. The unit of measurement for training expenditures per worker is thousand RMB. 
Table 3: Change in log wage for treated vs. control group firms

\begin{tabular}{lcccccccccc}
\hline Quantile & 1 & 2 & 3 & 4 & 5 & 6 & 7 & 8 & 9 & 10 \\
\hline Control & 0.960 & 0.377 & 0.281 & 0.242 & 0.221 & 0.226 & 0.204 & 0.197 & 0.189 & 0.187 \\
Treatment & 1.039 & 0.633 & 0.623 & 0.638 & 0.611 & 0.602 & 0.585 & 0.575 & 0.598 & 0.611 \\
\hline
\end{tabular}


Table 4: Change in log wage for treated vs. control group firms by ownership type

\begin{tabular}{|c|c|c|c|c|c|c|c|c|c|c|c|}
\hline & Quantile & 1 & 2 & 3 & 4 & 5 & 6 & 7 & 8 & 9 & 10 \\
\hline \multirow{2}{*}{$\stackrel{\circ}{\circ}$} & Control & 0.444 & 0.299 & 0.253 & 0.241 & 0.224 & 0.204 & 0.193 & 0.193 & 0.179 & 0.167 \\
\hline & Treatment & 0.753 & 0.619 & 0.624 & 0.599 & 0.575 & 0.560 & 0.570 & 0.592 & 0.574 & 0.589 \\
\hline \multirow{2}{*}{ O } & Control & 0.449 & 0.225 & 0.245 & 0.178 & 0.172 & 0.163 & 0.131 & 0.127 & 0.144 & 0.089 \\
\hline & Treatment & 0.675 & 0.480 & 0.438 & 0.411 & 0.334 & 0.339 & 0.351 & 0.344 & 0.332 & 0.456 \\
\hline \multirow{2}{*}{$\stackrel{\bigcirc}{Z}$} & Control & 0.518 & 0.386 & 0.379 & 0.310 & 0.305 & 0.276 & 0.244 & 0.238 & 0.181 & 0.188 \\
\hline & Treatment & 0.951 & 0.690 & 0.639 & 0.683 & 0.666 & 0.653 & 0.664 & 0.524 & 0.726 & 0.467 \\
\hline \multirow{2}{*}{ O } & Control & 0.570 & 0.382 & 0.380 & 0.330 & 0.317 & 0.264 & 0.296 & 0.231 & 0.210 & 0.197 \\
\hline & Treatment & 0.946 & 0.804 & 0.710 & 0.728 & 0.757 & 0.632 & 0.810 & 0.702 & 0.745 & 0.751 \\
\hline
\end{tabular}

Notes: LO refers to local privately or collectively owned firms, SO refers to state-owned enterprises, the non-mainland Chinese owned enterprises (NO) are those owned by investors from either Hong Kong, Macao or Taiwan and FO refers to foreign-owned enterprises. 
Table 5: Employment regression results

\begin{tabular}{lcc}
\hline & \multicolumn{2}{c}{ FE models } \\
& $(1)$ & $(2)$ \\
\hline Treatment dummy (lag) & $-0.075^{* * *}$ \\
& $(0.003)$ & \\
& & $-0.170^{* * *}$ \\
Treatment intensity (lag) & \multicolumn{2}{c}{$(0.009)$} \\
& $0.458^{* * *}$ & $0.455^{* * *}$ \\
Log workforce size (lag) & $(0.007)$ & $(0.007)$ \\
& $0.000^{* * *}$ & $0.000^{* * *}$ \\
Average wage (lag) & $(0.000)$ & $(0.000)$ \\
& $0.426^{* * *}$ & $0.422^{* * *}$ \\
Labor productivity (lag) & $(0.048)$ & $(0.048)$ \\
& $0.024^{* * *}$ & $0.024^{* * *}$ \\
Export intensity (lag) & $(0.004)$ & $(0.004)$ \\
& $0.198^{* * *}$ & $0.199^{* * *}$ \\
Profit margin (lag) & $(0.010)$ & $(0.010)$ \\
& $0.014^{* *}$ & $0.014^{* *}$ \\
State owned (lag) & $(0.006)$ & $(0.006)$ \\
& $0.006^{*}$ & $0.006^{*}$ \\
Foreign owned (lag) & $(0.004)$ & $(0.004)$ \\
& 0.003 & 0.003 \\
HK/MC/TW owned (lag) & $(0.004)$ & $(0.004)$ \\
\hline & 750877 & 750877 \\
& 255317 & 255317 \\
Observations & 0.288 & 0.287 \\
Firms & \multicolumn{3}{c}{$R^{2}$} & \\
\hline Notes: Standard errors are clustered at the county level and \\
displayed in parentheses. The respective significance symbols \\
denote: ${ }^{*} p<0.10{ }^{* *} p<0.05,{ }^{* * *} p<0.01$. & \\
& &
\end{tabular}


Table 6: Fixed capital investment regression results

\begin{tabular}{|c|c|c|}
\hline & \multicolumn{2}{|c|}{ GMM models } \\
\hline & (1) & (2) \\
\hline Treatment dummy (lag) & $\begin{array}{c}0.001 \\
(0.003)\end{array}$ & \\
\hline Treatment intensity (lag) & & $\begin{array}{r}-0.004 \\
(0.010)\end{array}$ \\
\hline Investment rate (lag) & $\begin{array}{c}-0.390^{* * *} \\
(0.142)\end{array}$ & $\begin{array}{c}-0.393^{* * *} \\
(0.142)\end{array}$ \\
\hline Change in log output & $\begin{array}{l}0.470^{* * *} \\
(0.062)\end{array}$ & $\begin{array}{l}0.471^{\text {*** }} \\
(0.062)\end{array}$ \\
\hline Change in log output (lag) & $\begin{array}{c}-0.249^{* * *} \\
(0.035)\end{array}$ & $\begin{array}{c}-0.250^{* * *} \\
(0.035)\end{array}$ \\
\hline Debt per capital & $\begin{array}{c}0.000 \\
(0.000)\end{array}$ & $\begin{array}{c}0.000 \\
(0.000)\end{array}$ \\
\hline Debt per capital (lag) & $\begin{array}{r}-0.000 \\
(0.001)\end{array}$ & $\begin{array}{r}-0.000 \\
(0.001)\end{array}$ \\
\hline Profit per capital & $\begin{array}{c}-0.004 \\
(0.005)\end{array}$ & $\begin{array}{r}-0.004 \\
(0.005)\end{array}$ \\
\hline Profit per capital (lag) & $\begin{array}{c}0.003 \\
(0.009)\end{array}$ & $\begin{array}{c}0.003 \\
(0.009)\end{array}$ \\
\hline Error correction term & $\begin{array}{c}-0.256^{* * *} \\
(0.035)\end{array}$ & $\begin{array}{c}-0.256^{* * *} \\
(0.035)\end{array}$ \\
\hline Average wage (lag) & $\begin{array}{c}-0.000 \\
(0.000)\end{array}$ & $\begin{array}{c}-0.000 \\
(0.000)\end{array}$ \\
\hline Observations & 222174 & 222174 \\
\hline Firms & 94938 & 94938 \\
\hline Number of instruments & 44 & 44 \\
\hline Hansen Test (p-value) & 0.482 & 0.486 \\
\hline AR(1) (p-value) & 0.011 & 0.011 \\
\hline AR(2) (p-value) & 0.290 & 0.281 \\
\hline
\end{tabular}


Table 7: Human capital investment regression results

\begin{tabular}{|c|c|c|c|c|}
\hline & \multicolumn{2}{|c|}{ Logit models } & \multicolumn{2}{|c|}{ Tobit models } \\
\hline & (3) & (4) & (5) & (6) \\
\hline Treatment dummy (lag) & $\begin{array}{c}-0.089^{* * *} \\
(0.000)\end{array}$ & & $\begin{array}{c}-0.014^{* * *} \\
(0.000)\end{array}$ & \\
\hline Treatment intensity (lag) & & $\begin{array}{c}-0.225^{* * *} \\
(0.000)\end{array}$ & & $\begin{array}{c}-0.036^{* * *} \\
(0.000)\end{array}$ \\
\hline Average wage (lag) & $\begin{array}{l}0.000^{* * *} \\
(0.000)\end{array}$ & $\begin{array}{l}0.000^{* * *} \\
(0.000)\end{array}$ & $\begin{array}{l}0.000^{* * *} \\
(0.000)\end{array}$ & $\begin{array}{l}0.000^{* * *} \\
(0.000)\end{array}$ \\
\hline Employees (lag) & $\begin{array}{l}0.439^{* * *} \\
(0.000)\end{array}$ & $\begin{array}{l}0.435^{* * *} \\
(0.000)\end{array}$ & $\begin{array}{l}0.028^{* * *} \\
(0.000)\end{array}$ & $\begin{array}{l}0.028^{* * *} \\
(0.000)\end{array}$ \\
\hline Labor productivity (lag) & $\begin{array}{l}0.557^{* * *} \\
(0.000)\end{array}$ & $\begin{array}{l}0.549^{* * *} \\
(0.000)\end{array}$ & $\begin{array}{c}-0.034^{* * *} \\
(0.000)\end{array}$ & $\begin{array}{c}-0.035^{* * *} \\
(0.000)\end{array}$ \\
\hline State owned & $\begin{array}{c}0.013 \\
(0.699)\end{array}$ & $\begin{array}{c}0.014 \\
(0.678)\end{array}$ & $\begin{array}{c}-0.004^{* *} \\
(0.018)\end{array}$ & $\begin{array}{c}-0.004^{* *} \\
(0.010)\end{array}$ \\
\hline Foreign owned & $\begin{array}{c}0.017 \\
(0.505)\end{array}$ & $\begin{array}{c}0.017 \\
(0.473)\end{array}$ & $\begin{array}{c}-0.017^{* * *} \\
(0.000)\end{array}$ & $\begin{array}{c}-0.017^{* * *} \\
(0.000)\end{array}$ \\
\hline Exporter dummy & $\begin{array}{l}0.142^{* * *} \\
(0.000)\end{array}$ & $\begin{array}{l}0.142^{* * *} \\
(0.000)\end{array}$ & $\begin{array}{c}0.002 \\
(0.104)\end{array}$ & $\begin{array}{c}0.002 \\
(0.122)\end{array}$ \\
\hline Union dummy & & & $\begin{array}{l}0.093^{* * *} \\
(0.000)\end{array}$ & $\begin{array}{l}0.093^{* * *} \\
(0.000)\end{array}$ \\
\hline Technical staff (\%) & & & $\begin{array}{l}0.114^{\text {*** }} \\
(0.000)\end{array}$ & $\begin{array}{l}0.114^{* * *} \\
(0.000)\end{array}$ \\
\hline University degree (\%) & & & $\begin{array}{l}0.356^{* * *} \\
(0.000)\end{array}$ & $\begin{array}{c}0.356^{* * *} \\
(0.000)\end{array}$ \\
\hline Female staff $(\%)$ & & & $\begin{array}{c}-0.081^{* * *} \\
(0.000)\end{array}$ & $\begin{array}{c}-0.081^{* * *} \\
(0.000)\end{array}$ \\
\hline Firm fixed effects & YES & YES & NO & $\mathrm{NO}$ \\
\hline Industry fixed effects & $\mathrm{NO}$ & $\mathrm{NO}$ & YES & YES \\
\hline Observations & 370591 & 370591 & 756511 & 756511 \\
\hline Log likelihood & -142146.8 & -142144.9 & -217787.7 & -217783.5 \\
\hline $\mathrm{Chi}^{2}$ & 1332.8 & 1274.0 & 36169.8 & 42488.2 \\
\hline Prob $\mathrm{Chi}^{2}>0$ & 0.000 & 0.000 & 0.000 & 0.000 \\
\hline$\sigma_{u}$ & & & $0.210^{* * *}$ & $0.210^{* * *}$ \\
\hline$\sigma_{e}$ & & & $0.203^{* * *}$ & $0.203^{* * *}$ \\
\hline$\rho$ & & & 0.517 & 0.517 \\
\hline
\end{tabular}


Table 8: Fixed capital investment regression results by firm ownership

\begin{tabular}{lcccc}
\hline & \multicolumn{4}{c}{ GMM models } \\
& LOEs & SOEs & NOEs & FOEs \\
\hline Treatment dummy (lag) & 0.005 & -0.005 & -0.004 & 0.002 \\
& $(0.004)$ & $(0.009)$ & $(0.010)$ & $(0.011)$ \\
Investment rate (lag) & -0.249 & $-0.087^{* *}$ & -0.074 & $-0.485^{* * *}$ \\
& $(0.221)$ & $(0.040)$ & $(0.246)$ & $(0.177)$ \\
Chang in log output & $0.328^{* * *}$ & 0.105 & $0.463^{* *}$ & $0.525^{* * *}$ \\
& $(0.102)$ & $(0.072)$ & $(0.183)$ & $(0.101)$ \\
Change in log output (lag) & $-0.166^{* * *}$ & -0.047 & $-0.224^{* *}$ & $-0.295^{* * *}$ \\
& $(0.055)$ & $(0.040)$ & $(0.090)$ & $(0.051)$ \\
Error correction term & $-0.166^{* * *}$ & -0.046 & $-0.227^{* * *}$ & $-0.320^{* * *}$ \\
& $(0.055)$ & $(0.043)$ & $(0.087)$ & $(0.050)$ \\
Average wage (lag) & -0.000 & -0.000 & 0.000 & -0.000 \\
& $(0.000)$ & $(0.000)$ & $(0.000)$ & $(0.000)$ \\
\hline Observations & 149300 & 18730 & 28452 & 26770 \\
Groups & 67860 & 8827 & 13758 & 12867 \\
Number of instruments & 18 & 36 & 24 & 32 \\
Hansen Test (p-value) & 0.642 & 0.251 & 0.521 & 0.152 \\
AR(1) (p-value) & 0.054 & 0.000 & 0.017 & 0.086 \\
AR(2) (p-value) & 0.762 & 0.175 & 0.400 & 0.176 \\
\hline
\end{tabular}

Notes: Standard errors are are clustered at the county level and displayed in parentheses. The respective significance symbols denote: ${ }^{*} p<0.10,{ }^{* *} p<0.05,{ }^{* * *} p<0.01$. The definitions of LOEs, SOEs, NOEs and FOEs are mentioned in the footnote of table 4. 


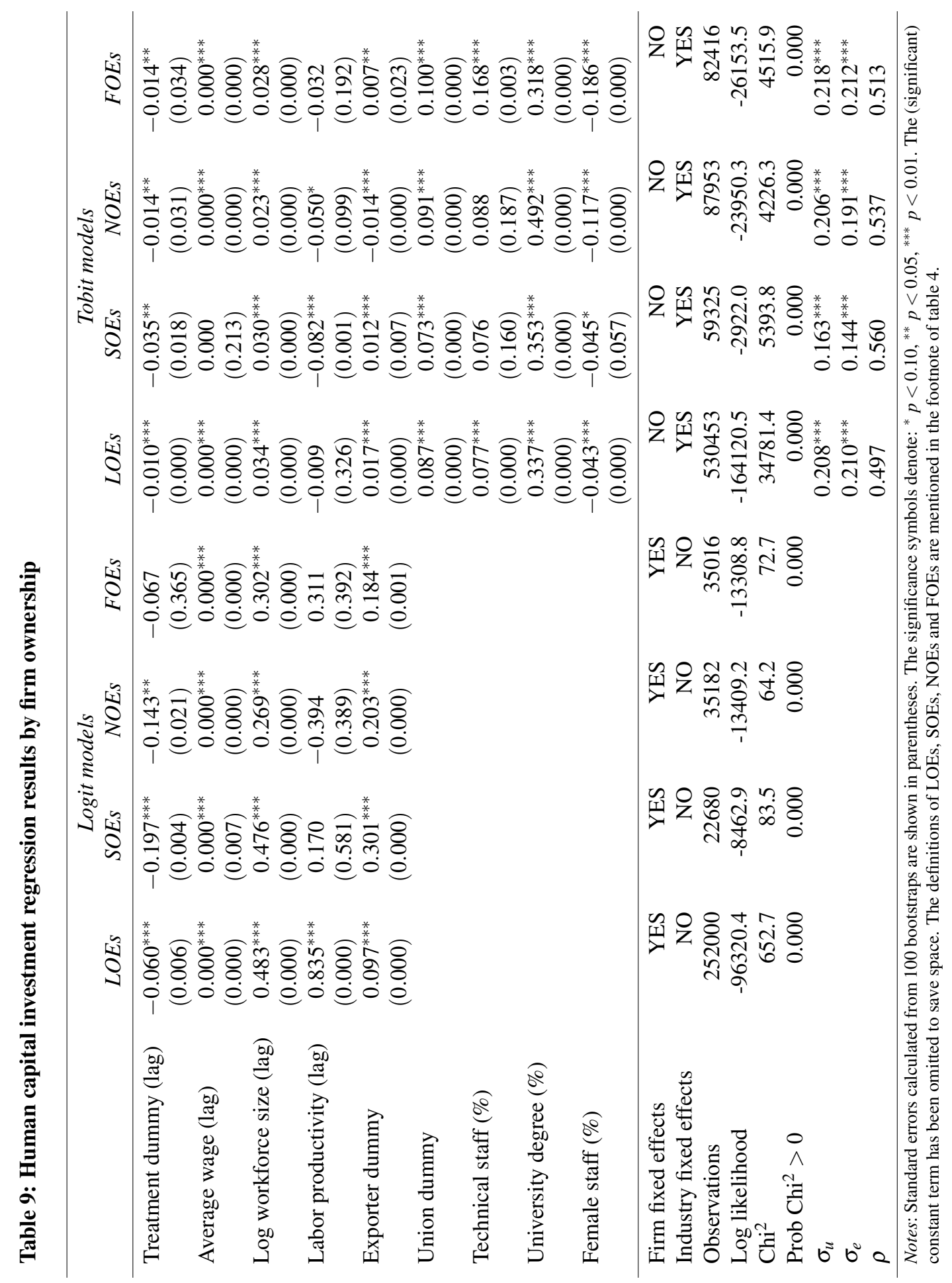


Table 10: Robustness checks: alternative treatment measure

\begin{tabular}{lcccc}
\hline & \multicolumn{2}{c}{ Fixed capital } & \multicolumn{2}{c}{ Human capital } \\
& $(1)$ & $(2)$ & $(3)$ & $(4)$ \\
\hline Treatment dummy (lag) & 0.004 & \multicolumn{3}{c}{$-0.002^{* *}$} \\
& $(0.003)$ & & $(0.001)$ & \\
Treatment intensity (lag) & & 0.019 & & $-0.023^{* *}$ \\
& & $(0.029)$ & & $(0.010)$ \\
\hline Observations & 62922 & 62922 & 84929 & 84929 \\
$R^{2}$ & 0.017 & 0.017 & 0.011 & 0.011 \\
\hline
\end{tabular}

Notes: Standard errors are clustered at the county level and displayed in parentheses. The respective significance symbols denote: ${ }^{*} p<0.10,{ }^{* *} p<0.05,{ }^{* * *} p<0.01$. The control variables included are wages, labor productivity, employment, profit margins, dummy variables for state-ownership, foreign-ownership and ownership by entities from Hong Kong, Macao or Taiwan, as well as dummy variables for cities and industries. 
Table A1: Effects of Labor Market Conditions on the Minimum Wage, 2004-2009

\begin{tabular}{|c|c|c|c|c|c|c|}
\hline \multicolumn{7}{|c|}{$\begin{array}{c}\text { Panel A: Normalized minimum wage } \\
\text { Dependent variable: Minimum-to-average-wage ratio }\end{array}$} \\
\hline Independent variables & (1) & (2) & (3) & (4) & $(5)$ & (6) \\
\hline GDP per capita & $\begin{array}{c}0.047 \\
(0.055)\end{array}$ & $\begin{array}{c}0.049 \\
(0.063)\end{array}$ & $\begin{array}{c}0.035 \\
(0.057)\end{array}$ & $\begin{array}{l}0.168^{* * *} \\
(0.062)\end{array}$ & $\begin{array}{l}0.175^{* * *} \\
(0.063)\end{array}$ & $\begin{array}{l}0.162^{* *} \\
(0.065)\end{array}$ \\
\hline Youth unemployment rate & $\begin{array}{r}-0.007 \\
(0.021)\end{array}$ & $\begin{array}{r}-0.007 \\
(0.021)\end{array}$ & $\begin{array}{r}-0.008 \\
(0.022)\end{array}$ & & & \\
\hline CPI & & $\begin{array}{c}1.168 \\
(0.864)\end{array}$ & $\begin{array}{c}1.230 \\
(0.900)\end{array}$ & & $\begin{array}{c}0.661 \\
(0.682)\end{array}$ & $\begin{array}{c}0.936 \\
(0.715)\end{array}$ \\
\hline FDI & & & $\begin{array}{r}-0.014 \\
(0.010)\end{array}$ & & & $\begin{array}{r}-0.008 \\
(0.010)\end{array}$ \\
\hline Unemployment & & & & $\begin{array}{c}-0.002 \\
(0.015)\end{array}$ & $\begin{array}{c}-0.002 \\
(0.015)\end{array}$ & $\begin{array}{c}-0.005 \\
(0.017)\end{array}$ \\
\hline Observations & 1640 & 1640 & 1640 & 1640 & 1640 & 1640 \\
\hline$R^{2}$ & 0.120 & 0.121 & 0.133 & 0.101 & 0.103 & 0.107 \\
\hline \multicolumn{7}{|c|}{$\begin{array}{l}\text { Panel B: Non-normalized minimum wage } \\
\text { Dependent variable: Minimum wage level }\end{array}$} \\
\hline Independent variables & (1) & (2) & (3) & (4) & (5) & $(6)$ \\
\hline GDP per capita & $\begin{array}{c}0.177 \\
(0.255)\end{array}$ & $\begin{array}{c}0.153 \\
(0.248)\end{array}$ & $\begin{array}{c}0.262 \\
(0.287)\end{array}$ & $\begin{array}{c}0.115^{* *} \\
(0.047)\end{array}$ & $\begin{array}{c}0.116^{* *} \\
(0.048)\end{array}$ & $\begin{array}{c}0.099^{*} \\
(0.051)\end{array}$ \\
\hline Youth unemployment rate & $\begin{array}{c}-0.113 \\
(0.527)\end{array}$ & $\begin{array}{c}-0.111 \\
(0.534)\end{array}$ & $\begin{array}{r}-0.099 \\
(0.543)\end{array}$ & & & \\
\hline CPI & & $\begin{array}{r}-0.572 \\
(0.422)\end{array}$ & $\begin{array}{r}-0.350 \\
(0.324)\end{array}$ & & $\begin{array}{c}-0.109 \\
(0.420)\end{array}$ & $\begin{array}{r}-0.257 \\
(0.435)\end{array}$ \\
\hline FDI & & & $\begin{array}{r}-0.168 \\
(0.295)\end{array}$ & & & $\begin{array}{r}-0.019 \\
(0.018)\end{array}$ \\
\hline Average wage & $\begin{array}{c}0.225 \\
(0.150)\end{array}$ & $\begin{array}{c}0.225 \\
(0.145)\end{array}$ & $\begin{array}{c}0.239 \\
(0.148)\end{array}$ & $\begin{array}{c}0.266^{*} \\
(0.149)\end{array}$ & $\begin{array}{c}0.267^{*} \\
(0.149)\end{array}$ & $\begin{array}{c}0.245 \\
(0.150)\end{array}$ \\
\hline Unemployment & & & & $\begin{array}{c}-0.009 \\
(0.013)\end{array}$ & $\begin{array}{c}-0.009 \\
(0.013)\end{array}$ & $\begin{array}{c}-0.010 \\
(0.015)\end{array}$ \\
\hline Observations & 1640 & 1640 & 1640 & 1640 & 1640 & 1640 \\
\hline$R^{2}$ & 0.323 & 0.334 & 0.339 & 0.270 & 0.290 & 0.292 \\
\hline
\end{tabular}

Notes: All regressions are estimated with year and county fixed effects. Dependent and independent variables are in logarithms. Cluster-robust standard errors at the county level are in parentheses. The respective significance symbols denote: ${ }^{*} p<0.10,{ }^{* *} p<0.05,{ }^{* * *} p<0.01$. 